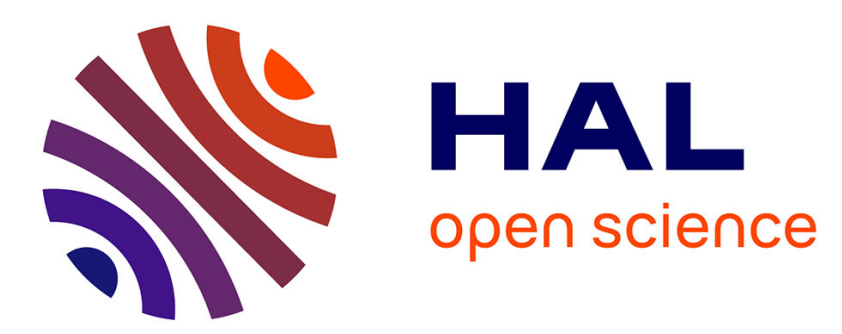

\title{
Flash Flood Prediction in Small to Medium-Sized Watersheds. Case Study: Bistra River (Apuseni Mountains, Romania)
}

Ionel Haidu, Carina Strapazan

\section{- To cite this version:}

Ionel Haidu, Carina Strapazan. Flash Flood Prediction in Small to Medium-Sized Watersheds. Case Study: Bistra River (Apuseni Mountains, Romania). Carpathian Journal of Earth and Environmental Sciences, 2019, 14 (2), pp.439-448. 10.26471/cjees/2019/014/093 . hal-02488123

\section{HAL Id: hal-02488123 \\ https://hal.univ-lorraine.fr/hal-02488123}

Submitted on 22 Feb 2020

HAL is a multi-disciplinary open access archive for the deposit and dissemination of scientific research documents, whether they are published or not. The documents may come from teaching and research institutions in France or abroad, or from public or private research centers.
L'archive ouverte pluridisciplinaire HAL, est destinée au dépôt et à la diffusion de documents scientifiques de niveau recherche, publiés ou non, émanant des établissements d'enseignement et de recherche français ou étrangers, des laboratoires publics ou privés. 


\title{
FLASH FLOOD PREDICTION IN SMALL TO MEDIUM-SIZED WATERSHEDS. CASE STUDY: BISTRA RIVER (APUSENI MOUNTAINS, ROMANIA)
}

\author{
Ionel HAIDU ${ }^{1}$ \& Carina STRAPAZAN ${ }^{2 *}$ \\ ${ }^{1}$ University of Lorraine, Laboratory LOTERR - EA 7304, Ile du Saulcy, 57045 Metz, France, e-mail: ionel.haidu@univ- \\ lorraine.fr \\ ${ }^{2 *}$ Corresponding author: Babeş-Bolyai University, Faculty of Geography, 5-7, Clinicilor Street, 400006, Cluj- \\ Napoca, Romania, email: carinastrapazan@yahoo.ro
}

\begin{abstract}
Romania is among the European countries which are still susceptible to flood disasters. Climate change, the lack of a sustainable land management and floods approach are the most important driving factors of flood risk. Accordingly, additional research to improve or develop various methods for predicting the flash flood events, especially within densely populated watersheds, is required. This paper aims to provide a further assessment of the reliability of a distributed hydrological model developed within a GIS framework The model was developed for use in small river basins and so forth, another objective is to provide insight into whether it is acceptable for use in larger-sized watersheds than the ones it was created for. The methodology is presented by computing the discharges at the entrance of six human settlements located within the Bistra river watershed, a left-bank tributary of Barcău river (Bihor department, Romania). The chosen study area is frequently impacted by flooding, endangering the socio-economic activities, human settlements and infrastructure. A distributed hydrological modeling approach and the SCS-CN method are used in this research. The results revealed a good correlation between the estimated and measured hydrographs at the gauging points of Pădurea Neagră (upstream) and Chiribiș (located at the downstream end of the drainage basin).
\end{abstract}

Keywords: hydrographs, surface runoff, GIS, SCS-CN method, distributed hydrological model, settlements.

\section{INTRODUCTION}

The vulnerability to heavy rainfall events has been continuously increasing, especially during the past few years all over the world. Such events triggered severe flooding at both regional and global scales (e.g. 20th of May 2010, Poland; 15th of June, 2010, France, 16th of June, Bangladesh, 12th of January, 2012, Germany) (Liu \& Wang, 2013). Globally, floods caused 6.8 million deaths in the 20th century and 539811 deaths from 1980 to 2009 with more than 2.8 billion people being affected (Doocy et al., 2013).

Given the fact that over the past half century the population has experienced an exponential growth in hazardous areas (Khaleghi \& Mahmoodi, 2017), there is an increased potential impact of flooding.

In Europe there were 9500 human casualties and economic losses registered in the 20th century (Arseni et al., 2017; Dysarz et al., 2015).

In Romania, even if the flood prevention infrastructure has been strengthened in the low lying areas of the main rivers, most mountainous regions continue to face flooding issues because of the limited protection against flooding. The uncontrolled deforestation in these areas over the last decades, resulted in a higher overland flow which concentrates as flash floods (Domnița, 2012). Thus, the changes in land use may affect not only the soil erosion and its properties (Szilassi et al., 2006) but also the hydrological processes within a basin.

The catastrophic consequences such as flash floods and the related negative effects still are strongly felt by many regions in Romania, particularly by the populated areas of small to midsized watersheds with a precarious state or even lack 
of flood protection infrastructure. According to ABAC (2009), the small water courses have a catchment area between 10 and 100 sq.km and the medium watersheds cover areas smaller than 1000 sq.km. Likewise, the scarcity of the gauging station networks provides limited comprehension of hydrological processes in the catchment areas.

The literature abounds with methods and techniques developed or used to estimate the hydrological behavior of watersheds in order to help the local authorities to mitigate the effects of flooding.

There is a growing interest for integrating the hydrological modeling with GIS due to the effective capacity of the latter to manipulate and analyze various spatial data. The traditional lumped hydrologic models, specifically the unit hydrograph method, lack accounting for the spatial variability of hydrologic processes and properties of a catchment area (Maidment et al., 1996). The advancement of GIS and computer technologies along with the rapid growth of the availability of spatial data allowed for a distributed modeling approach with reduced data processing times and increased analysis capacity (Vieux, 2004).

Many studies around the world have confirmed the efectiveness of integrating the SCS-CN (Soil Conservation Service Curve Number) method with GIS techniques: Melesse et al., 2003; Melesse \& Graham, 2004; Satheeshkumar et al., 2017; Crăciun et al., 2007; Crăciun et al., 2009; Şarpe \& Haidu, 2017; Voda et al., 2018; Haidu et al., 2019. The CN index which is the main parameter used for runoff estimation (Strapazan \& Petrut, 2017), is based on the physical characteristics of watersheds that influence or generate runoff, namely the land use, soil type and texture and the antecedent moisture conditions (Gyori et al., 2016).

Several studies concerning the risk of flash floods in the Apuseni Mountains (Romania), have described the initial versions and the evolution of a hydrological GIS model adapted for very small watersheds as the ones conducted by Domnița et al., 2009, Domnița et al. 2010a, 2010b, Crăciun, 2011; Domnița, 2012, Gyori, 2013 and Haidu et al., 2017.

The flow path and travel time can be easily computed based on velocity, this latter parameter being the only one that requires exclusive estimations (Domnita et al., 2009). Based on the travel time, the time-area diagram (TAD) can be derived, by dividing the watershed into zones of constant travel time (isochrones) and the excess runoff for each isochrones can then be routed to the catchment outlet.

Given this new automated approach for rainfall-runoff modelling, and therefore the shortage of validation studies, the developed methodology is subject to further evaluation. The model integrates both the SCS-CN and rational methods, but the current study opted for the former since the chosen catchment for the case study covers a large area of 172 sq.km.

The overall aim of this paper is to assess the suitability of an automated GIS-based distributed hydrological model developed for very small-sized watersheds (Haidu et al., 2017) through validation of the modelled runoff using measured discharge data, and to present the methodology for flash flood prediction at the entrance of six human settlements located within the Bistra river watershed, a left-bank tributary of Barcău river. The reason is that a rainfallrunoff model offering good performance in data limited areas, as in this case, would serve as a useful tool for runoff prediction (Liptay et al., 2018).

Even if the model was created for small-sized watersheds, another aim is to check the model performance when being used on a medium-sized one $\left(172 \mathrm{~km}^{2}\right)$ with limited high quality data available.

The model is based on the SCS-CN method for the rainfall excess and runoff coefficient computation to serve as input data in the rational method applied for discharge estimation for each pixel on the raster data on the basis of the cell area, runoff coefficient and rainfall (Haidu et al., 2017). The current research was based only on the first method for all calculations, including discharges.

The Bistra river basin was chosen because the settlements located along the main river and its major tributaries, were exposed to several major past floods and still are vulnerable to such events.

\section{STUDY AREA AND DATA}

The Bistra river is the largest left-hand tributary of the Barcău river, their networks being monitored by the Crișuri Water Basin Administration, Oradea.

For the purpose of this study, precipitation data was collected from 5 hydrometric and rain gauge stations located within and in close proximity to the watershed (Pădurea Neagră, Chiribiș, Marca, Balc, and Borod) for a flash flood event that occurred between 16th and 18th of May 2012. This period was chosen because hourly rainfall values were available from the Chiribiş gauge station and the flow variations were recorded at both of the basin`s gauge stations, for a better rainfall-runoff model performance and validation. This rainfall event was also the second major one recorded by the Pădurea Neagră station between 1995 and 2016.

The Bistra drainage basin encompasses an area of 172 sq.km, being monitored by Pădurea Neagră 
and Chiribiş gauge stations, in the upstream sector and the downstream one, respectively. Upstream of the Pădurea Neagră gauge point, the river collects its waters from the northern slopes of the Plopis, Mountains, part of the larger Apuseni range. The largest tributaries of the above mentioned river are the Cuzap, Varvizel and Rovine rivers, while the rest are seasonal streams that may cause floods during torrential rainfall events (Fig. 1).

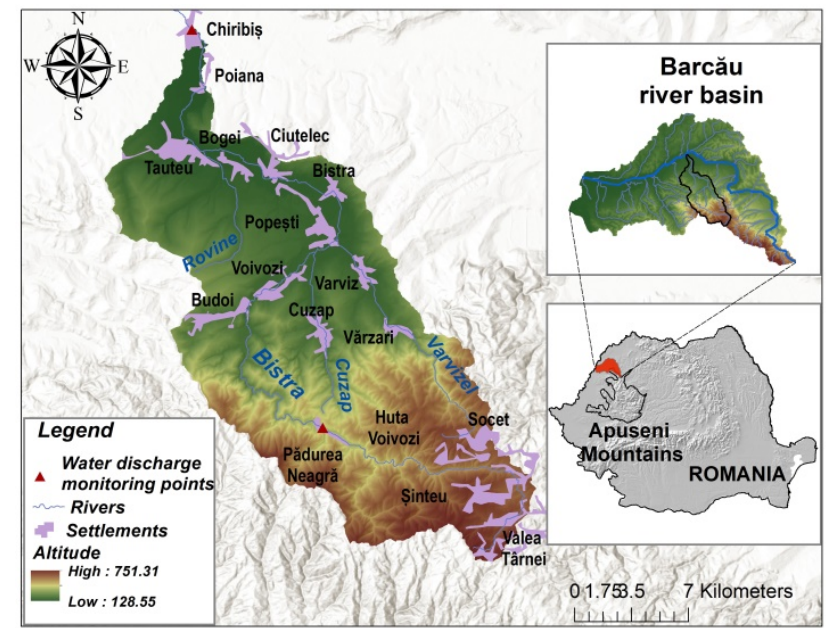

Figure 1. Location map of the study area.
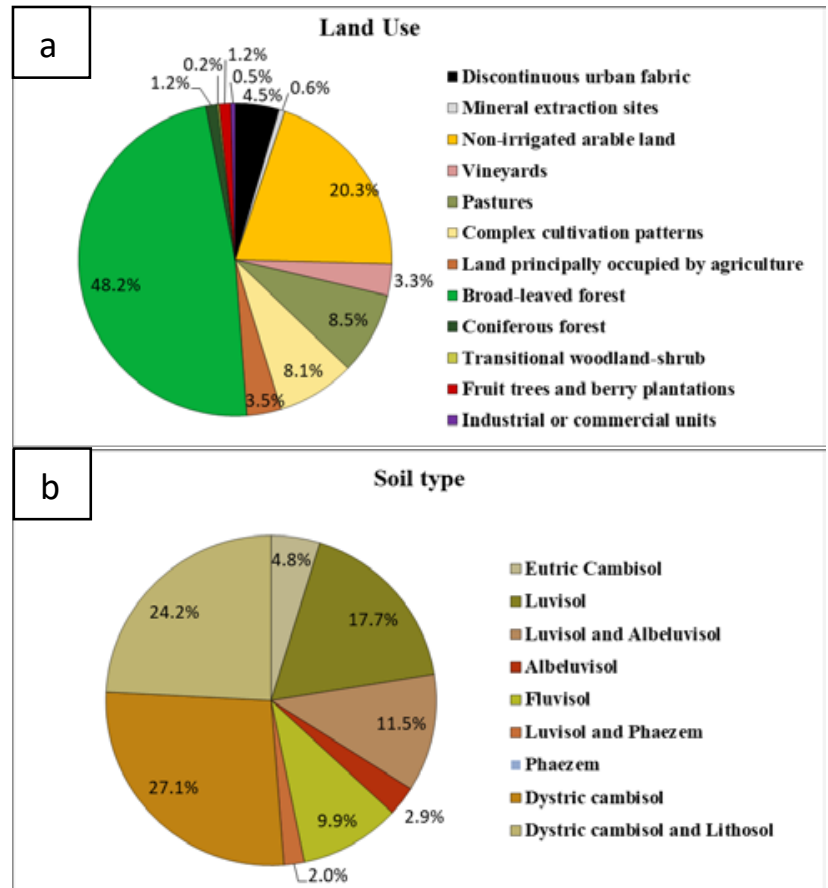

Figure 2. the area in percentage of land use/ land cover based on the CORINE Land Cover 2012 database (a) and different soil types (b).

Most of the settlements are located along the main river valley (Pădurea Neagră, Budoi, Voivozi, Popești, Bistra, Ciutelec, Poiana and Chiribiș) and its major tributaries (Cuzap, Vărzari, Varviz). The entry points of the main settlements from the upper, middle and lower sectors of the Bistra basin were chosen to exemplify the estimated discharge dynamics within the study area. The catchment area has a high forest cover (49,4 \%, 85 sq.km respectively) with broad-leaved and coniferous forests representing $48,2 \%$ and $1,2 \%$ of the total land area, respectively (Fig. 2, Table 1).

The large extent of forests has major implications on hydrologic processes, regulating the runoff processes due to tree canopy interception, reduced runoff rate and velocity.

The predominant soil types in the watershed area are Dystric Cambisols (covering 27,1\% of the total area), Dystric Cambisols associated with Lithosols (24, 2\% of the total area) with medium permeability and texture, and Luvisols (17, $7 \%$ of the total area) with medium to fine texture and low water permeability.

\section{METHODOLOGY}

\subsection{Description of methods and materials}

The event-based runoff model determines the flood hydrograph based on the given rainfall event and watershed characteristics.

The workflow consists of 4 incorporated modules that were implemented in ArcGIS Model Builder, a step for flow velocity computation in SAGA GIS and 5 MATLAB scripts (Gyori, 2013).

This distributed model works on a raster cell level and automatically calculates the discharge in every pixel without having to predefine the calculation sections and subcatchments, before the modelling process (Haidu et al., 2017).

The automation of the geoprocessing tasks was implemented in ArcGIS Model Builder. The surface runoff for each grid cell was computed and then, routed across hillslopes and through the main channel network, using isochrones of equal travel time (1 min). The final hydrograph was generated through a MATLAB script that processed and interpolated the discharge values computed for each isochrone.

The input data necessary to run the developed model includes the digital elevation model, rainfall, antecedent moisture conditions, land use, soils and flow velocity layers (Fig. 3).

The 2-meter resolution digital surface model was acquired based on LiDAR (Light Detection and Ranging) techniques and the ArcHydro tools were used to process it and delineate the watershed, the entire workflow being automated in ArcGIS Model Builder and presented in a previous research conducted by Strapazan \& Petruț, 2017.

The spatial representation of rainfall amounts and antecedent moisture conditions (AMC) was 
based on the widely known GIS Inverse Distance Weighted (IDW) interpolation method. The IDW technique relies on the inverse of the distance between a set of data or measured points.

This method was considered to be the most relevant for the study because in this case, altitude did not have a major influence on the spatial variability of precipitation, according to the available data from the gauge stations. Nevertheless, it should be pointed that a comprehensive analysis regarding this matter couldn't have been conducted, given the sparse rain gauge network area

The Soil Conservation Service Curve Number (CN) grid was developed with the support of the soil map (for hydrologic soil groups classification) provided by the National Research and Development Institute for Soil Science, Agrochemistry and Environment (ICPA), Bucharest combined with the Corine Land Cover (CLC) 2012 database for landuse.

The CN grid was then adjusted according to the selected event's antecedent moisture conditions in order to obtain the final CN map (Fig. 4), on the basis of the available equations in the literature.

That component of the net precipitation which does not infiltrate into the soil, gives the surface runoff (Barta, 2004).

The method utilized for surface runoff estimation in each grid cell, was the one presented by Crăciun et al. (2009), who developed and later upgraded the model by including a theoretical runoff coefficient computed on the basis of the watershed`s main characteristics affecting the hydrological processes such as the soil texture, landuse and slope.

In order to calculate the surface runoff for each grid cell, the equation that takes into account the cumulative water infiltration, was utilized (Musy \& Higy, 1998):

$$
Q=P-I_{a}-F
$$

Where:

$\mathrm{Q}$ - runoff (mm);

$\mathrm{P}$ - rainfall (mm);

Ia - initial abstraction ( $\mathrm{mm}$ );

$\mathrm{F}$ - cumulative infiltration ( $\mathrm{mm}$ ).

In order to estimate the water volume, the cell area and the excess rainfall were multiplied, an approach that accounts for the spatial variability of the latter, unlike the traditional time-area method which would involve a constant excess rainfall for the whole catchment area (Melesse et al., 2003).

For the travel time computation, the hillslope overland and channel flow velocities, along with the flow length layers were required.

The computation of the spatial flow velocity distribution was assessed using the SAGA GIS Isochrones Variable Speed module created by Olaya (2004), based on the Manning formula.

The Manning's roughness coefficients were determined based on the terrain land use and tables found in literature.

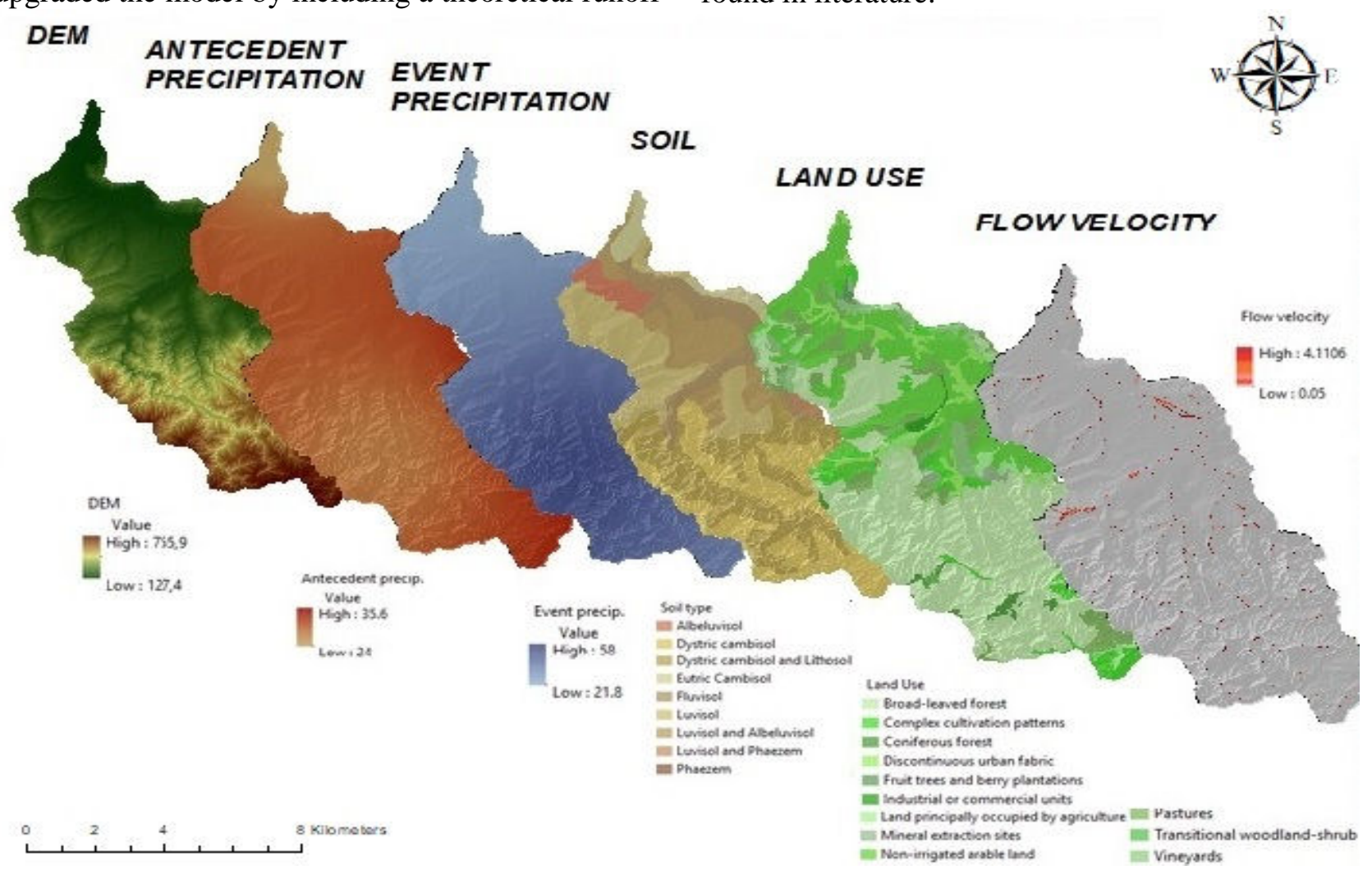

Figure 3. GIS layers used as input data for the runoff model. 


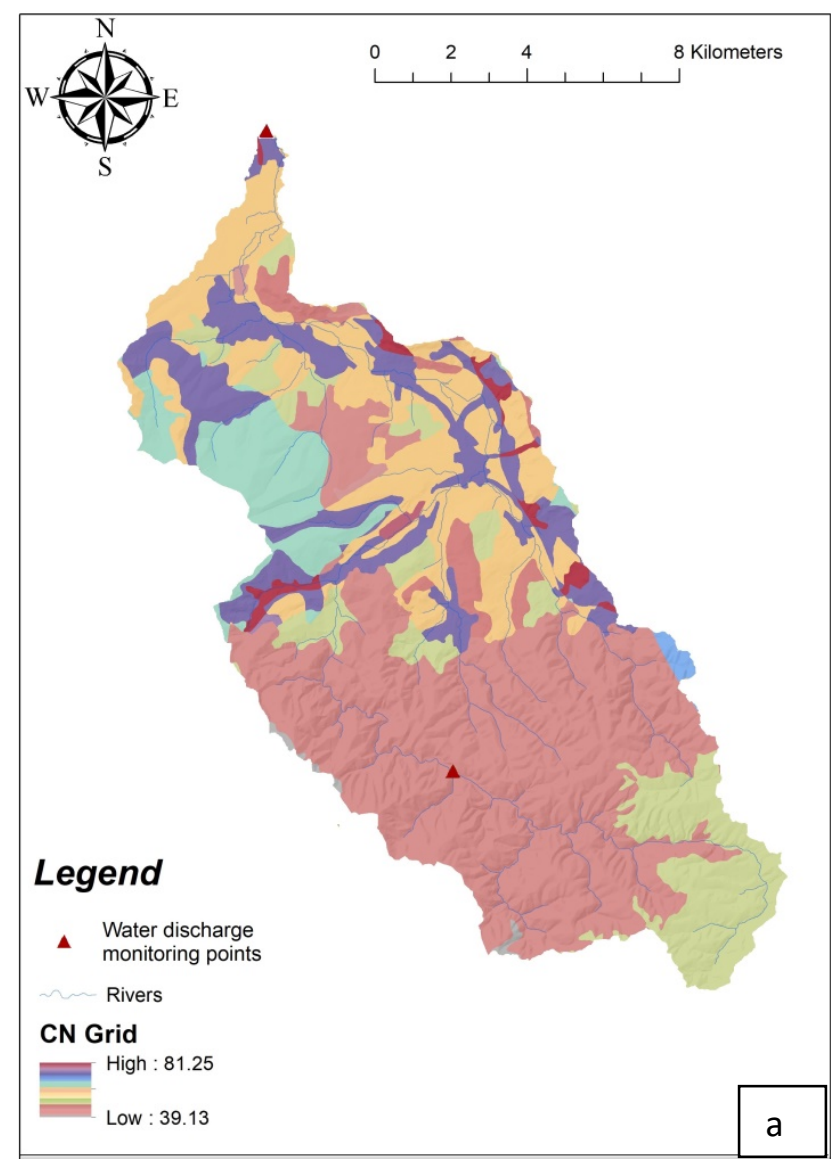

Figure 4. The spatial distribution of CN index (a) and surface runoff (b).

The total travel time from each cell in the grid to the outlet was estimated using the Weighted flow length GIS function, and reclassified using equal intervals of 1 minute (isochrones), (Domnița et al., 2010b).

The runoff hydrographs were estimated based on the travel time and the Zonal Statistics tabular data representing the cumulated discharge for each area between two consecutive isochrones.

Since the Zonal Statistics tool in ArcMap, performs a variety of calculations, and returns a table containing the computed values for predefined zones, the SUM column includes the total value of discharges computed for each isochrone (Gyori, 2013).

The table results were ultimately imported in MATLAB where the scripts created by Domnița (2012) were run. These scripts take into account the rainfall event duration, computing simultaneously the discharges during each time step and the runoff routing until the total travelling time is reached.

\subsection{Validation and statistics}

Records of rainfall intensity and duration were available from the downstream Chiribiș gauge station. In this manner, the 16th of May, 2012, 4:00

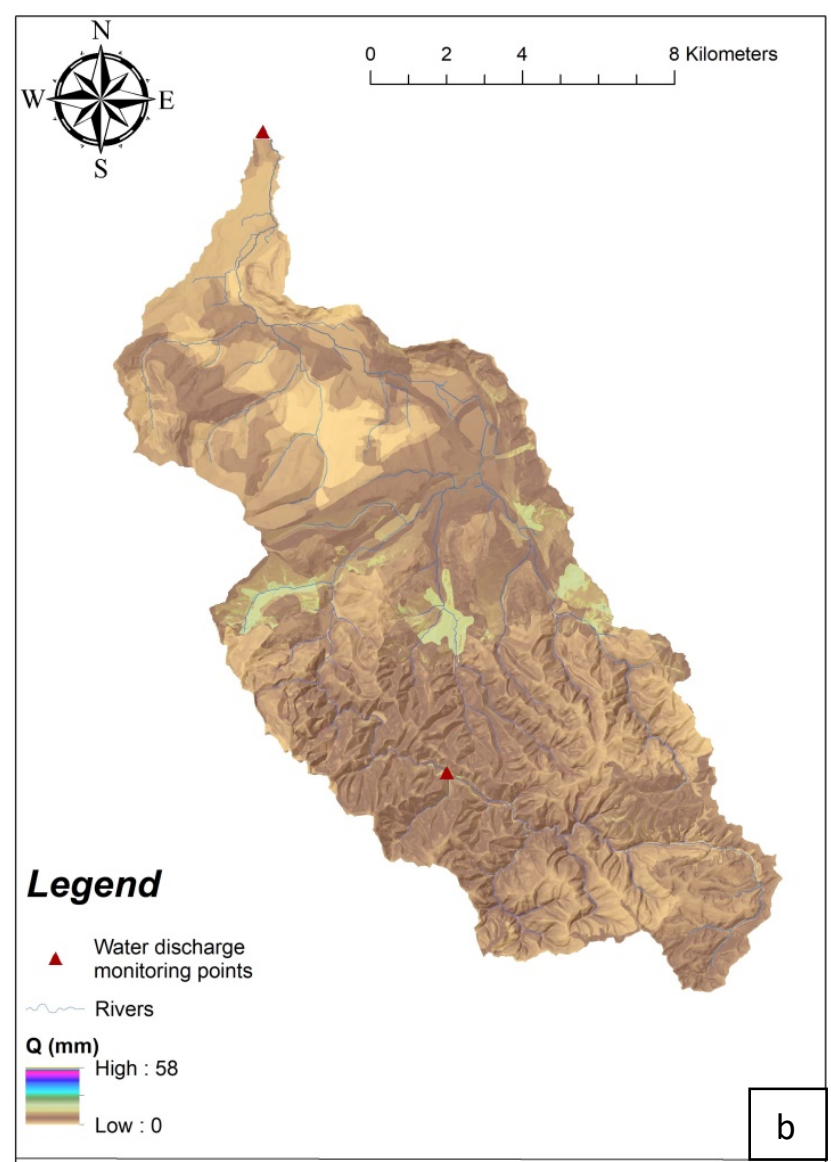

PM marks the start of the rainfall event, recorded at the Chiribis gauge station, which caused the rapidly increase of Bistra's water level. The precipitation lasted 22 hours, being a moderate, long-duration event, yet leading to increased runoff originating from the upstream areas. As for the Pădurea Neagră gauge station and the other monitoring points this type of information was unavailable. Consequently, having analyzed the flow records, it was assumed that the rainfall event started on May 17, 2012, 6:00 AM and that it has persisted for 5 hours.

Considering the available flow information from the two gauge stations within the catchment area, the validation procedure was extended by correlating the discharge data at both of the above mentioned monitoring points. Thus, the validation process not only does it take into account the whole model or watershed, but it also accounts for the spatial distribution of the discharge data within the same time frame in both upstream and downstream catchment areas. It should be mentioned that the model only takes into account the surface runoff produced by a rainfall event and not the groundwater, subsurface, and base flows (Crăciun, 2011). On that account, the baseflow was added to the direct runoff hydrograph based on the measurements prior to the storm. 
The baseflow separation procedure was performed using the CAVIS software and the constant slope model, developed by Corbuș (2010):

$$
Q_{b}(t)=Q_{b}(t-\Delta t)+\Delta Q_{b c}
$$

Where:

$\mathrm{Q}_{\mathrm{b}}(\mathrm{t})$ - baseflow at the moment $\mathrm{t}(\mathrm{m} 3 / \mathrm{s})$;

$\Delta \mathrm{t}$ - timestep

$\Delta \mathrm{Q}_{\mathrm{bc}}$ - increasing gradient of the baseflow discharges

In order to assess the accuracy of the model the Nash-Sutcliffe Efficiency (NSE) and the percent error in peak flow (PEP) were used.

The NSE is an index showing how much the observed versus estimated data deviates from the linear 1:1 relationship (Moriasi et al., 2007):

$$
N S E=1-\left[\frac{\left.\sum_{i=1}^{n}\left(X_{o b s, i}-X_{s i m, i}\right)\right)}{\sum_{i=1}^{n}\left(X_{o b s, i}=\overline{X_{o b s}}\right)}\right]
$$

Where:

$X_{o b s, i}$ - the $i$ th observed value;

$X_{\text {sim }, i}$ - the $i$ th simulated value;

$\overline{X_{o b s}}$ - the mean of observed data;

$n$ - the number of observations.

The PEP is a measure of fit between the peak flows of the computed and observed hydrographs (USACE, 2000):

$$
P E P=100\left|\frac{q_{\text {sim }}(\text { peak })-q_{\text {obs }}(\text { peak })}{q_{\text {obs }(\text { peak })}}\right|
$$

Where:

$\mathrm{q}_{\text {sim }}$ (peak) - the computed peak flow;

qobs (peak) - the observed/measured peak flow.

\section{RESULTS}

The travel time grid and the associated timearea histogram, (Fig. 5) reflect the elongated shape of a larger watershed with a typically longer time of concentration than would be normally estimated for small and circular basins.

It is worth mentioning that, as is the case with any other model, errors and discrepancies in the results may be caused by the input data, or the inner structure of the model (Centeri et al., 2009).

The results obtained by running the model both at the gauge locations and the other points of interest within the catchment area, are presented in figure 6 , table 1 and figure 7 . An increase in discharge values from the upstream to downstream sectors of the river basin can be observed.

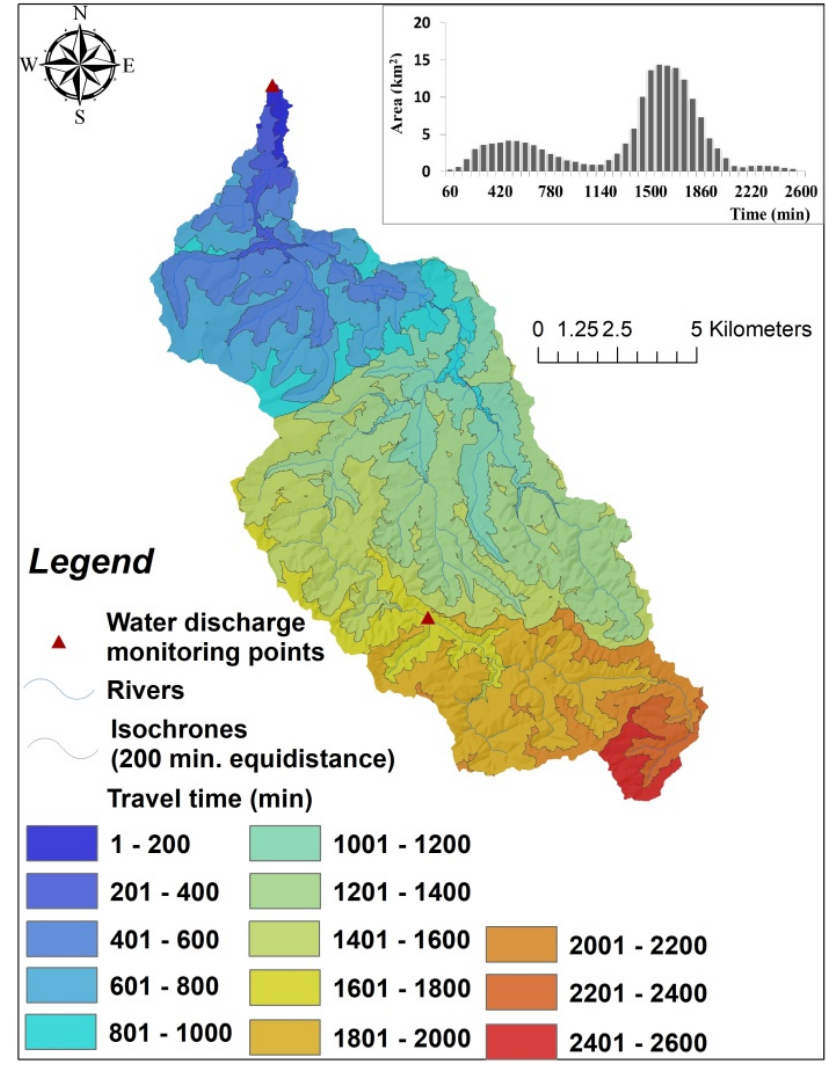

Figure 5 . The travel time map and the time-area diagram.

Between the Bistra, Tăuteu and Chiribiş sections there are no significant changes regarding the maximum discharge values, because another flood wave with a significantly smaller peak is simulated.

The reason lies in the fact that the model predicts a faster response time of the downstream areas than in reality. The lag in runoff coming from the upstream areas can be attributed to the forest's capacity to delay the flow towards the catchment outlet due to the high soil storage and canopy interception capacity. This is due to the fact that the watershed has more densely forested areas in the low and middle sectors.

The baseflow model assumes that the flow from aquifers is higher towards the end of the event, the separation being done by drawing a line connecting the beginning of the storm hydrograph to the inflection point of the recession limb. Therefore the baseflow is increasing during a rainfall event due to the increasing gradient of the discharges. Having added the baseflow to the estimated hydrographs, a good match with the measured ones was observed. Even if the hydrographs and their shapes were not perfectly simulated, in both cases they are similar, having relatively steep rising and gradual recession limbs (Fig. 8).

The relatively less accurate fit of the rising limb for Pădurea Neagră may be caused by a discrepancy between the computed and actual flow 


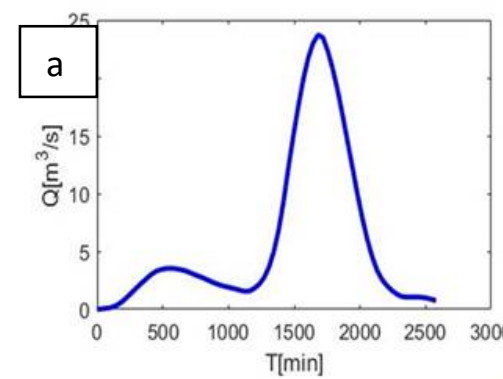

.........
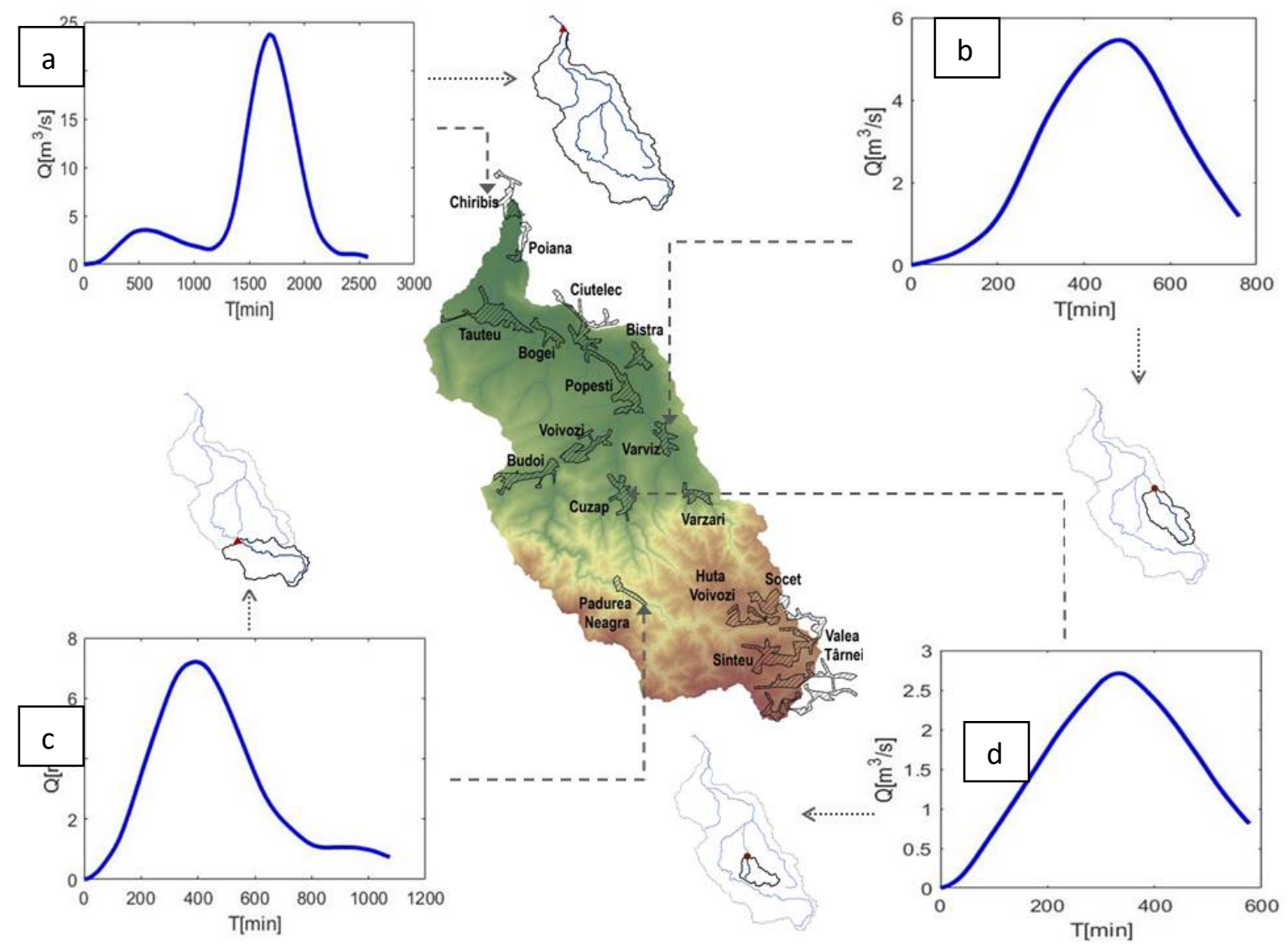

Figure 6. Computed hydrographs for the Chiribiș (a) and Pădurea Neagră (c) gauge stations and at the entrance of the Varviz (b) and Cuzap (d) settlements.

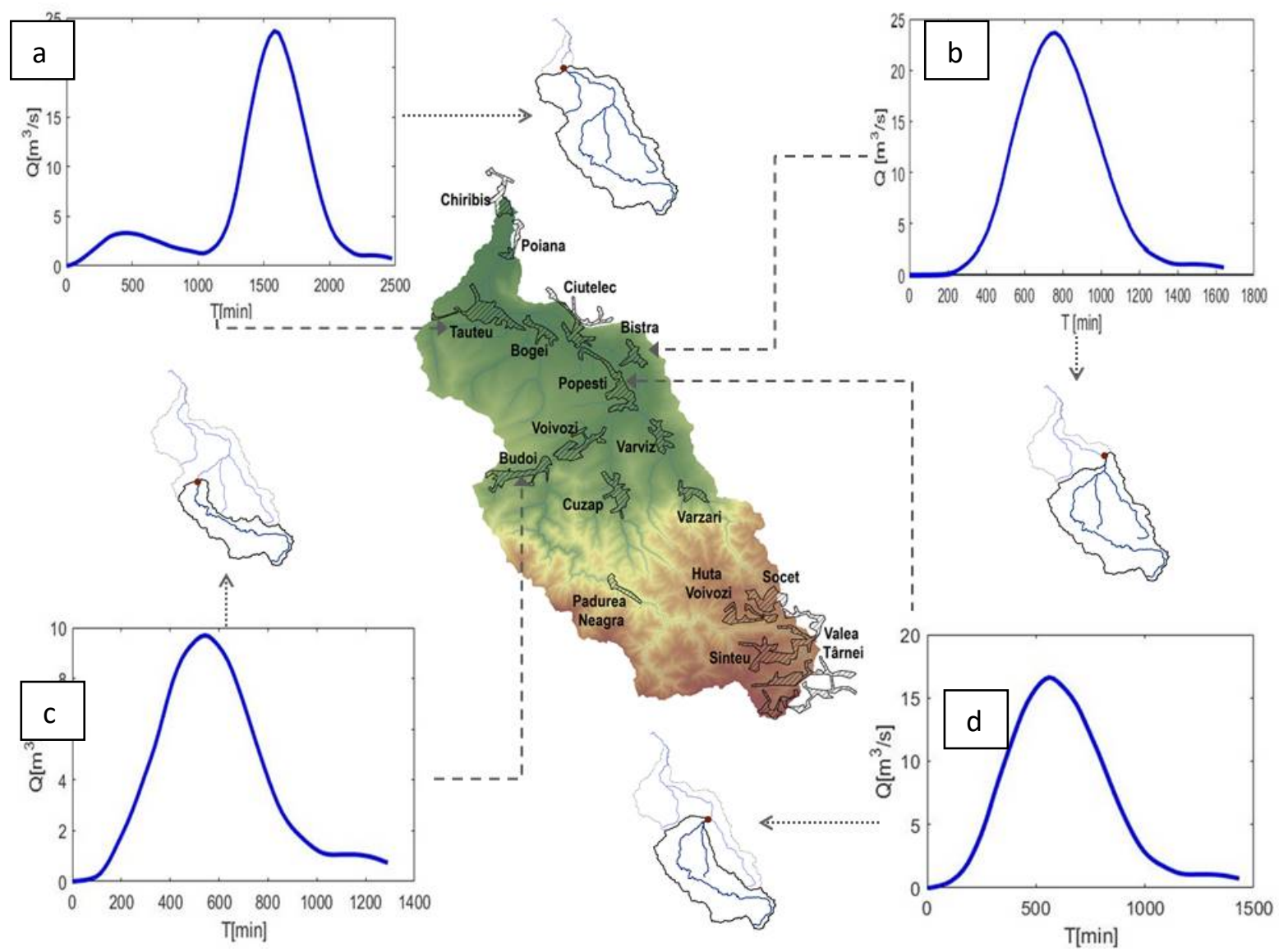

Figure 7. Computed hydrographs at the entrance of the Tăuteu (a), Bistra (b), Budoi (c) and Popești (d) settlements. 
Table 1. The morphometric parameters and the discharge values computed for the entrance of the main settlements.

\begin{tabular}{|c|c|c|c|c|c|c|c|c|}
\hline River & $\begin{array}{c}\text { Gauge } \\
\text { station*/Settlement }\end{array}$ & $\begin{array}{c}\text { Area } \\
\left(\mathrm{km}^{2}\right)\end{array}$ & $\begin{array}{c}\text { Travel } \\
\text { time } \\
(\mathrm{min})\end{array}$ & $\begin{array}{c}\mathrm{Q} \\
\left(\mathrm{m}^{3} / \mathrm{s}\right)\end{array}$ & $\begin{array}{c}\mathrm{q} \\
(\mathrm{l} / \mathrm{s} / \\
\mathrm{km} 2)\end{array}$ & $\begin{array}{c}\text { Agricultural } \\
\text { areas } \\
(\%)\end{array}$ & $\begin{array}{c}\text { Forests } \\
(\%)\end{array}$ & $\begin{array}{c}\text { Artificial } \\
\text { surfaces } \\
(\%)\end{array}$ \\
\hline Bistra & Pădurea Neagră & 39 & 1073 & 7.2 & 184.6 & 31.5 & 67.6 & 0.9 \\
\hline Bistra & Budoi & 57 & 1288 & 9.7 & 170.2 & 24.5 & 74.6 & 0.9 \\
\hline Bistra & Popești & 91 & 1434 & 16.6 & 182.4 & 32.3 & 63.9 & 3.8 \\
\hline Bistra & Bistra & 124 & 1640 & 23.7 & 191.1 & 36.0 & 59.6 & 4.4 \\
\hline Bistra & Tăuteu & 163 & 2472 & 23.7 & 145.4 & 42.4 & 52.4 & 5.2 \\
\hline Cuzap & Cuzap & 10 & 575 & 2.7 & 270.0 & 1.2 & 97.9 & 1.0 \\
\hline Varvizel & Varviz & 23 & 758 & 5.5 & 239.1 & 28.3 & 67.7 & 4.0 \\
\hline Bistra & Chiribiș* & 172 & 2577 & 23.8 & 138.4 & 45.0 & 49.4 & 5.6 \\
\hline
\end{tabular}
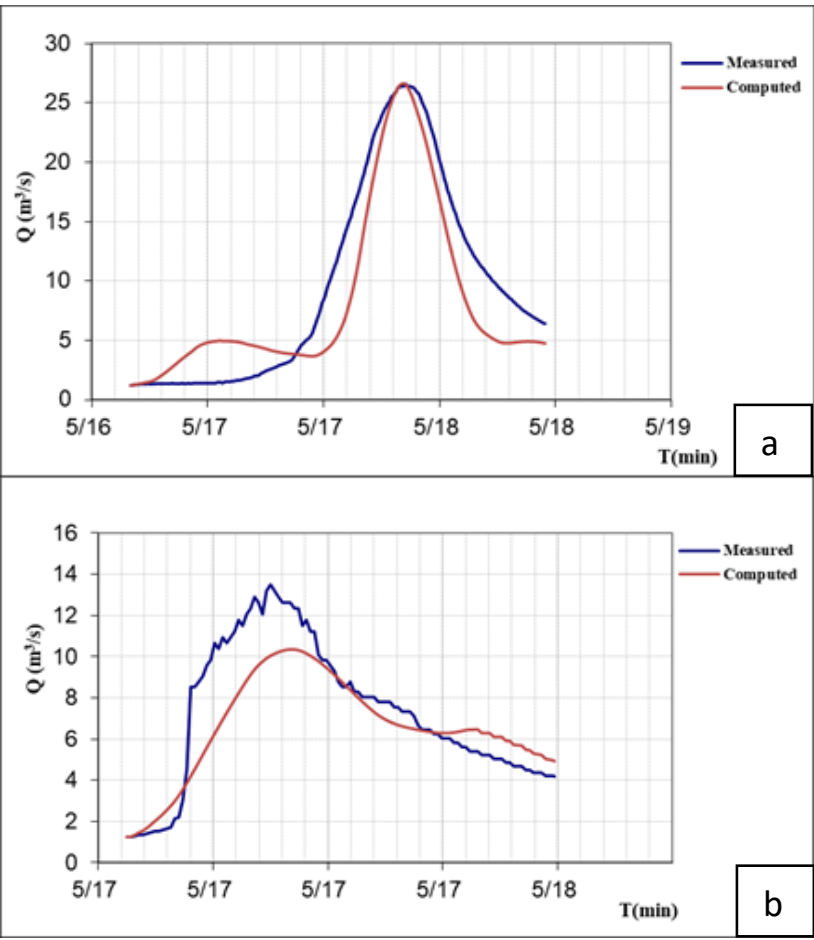

Figure 8. Comparison between measured and computed hydrographs at the Chiribiș (a) and Pădurea Neagră (b) monitoring stations.

velocities strongly influencing the travel time. This is due to the fact that SAGA GIS module only accounts for an average rainfall intensity over the entire watershed and not the spatial distribution of rainfall rates. This is also reflected in the above-mentioned and inaccurate fast responding areas which strongly influence the flood hydrograph geometry for Chiribiș monitoring point.

The fact that the actual short-term discharge fluctuations and peak flows at the Pădurea Neagră gauging point were not properly simulated, can be attributed to the limited number of rain gauges in the headwater areas and the lack of available rainfall intensity and duration data from the main monitoring station.

The calculation of the NSE resulted in values of 0.84 and 0.73 for the Chiribis and Pădurea Neagră sectors. Since all the values in the interval $[0.0,1.0]$ correspond to a satisfactory model performance (Moriasi et al., 2007), the results indicate a good fit between the expected and the measured values, especially for the Chiribis monitoring sector, where the NSE value is closer to 1 . The $0.15 \%$ PEP value for the Chiribiș gauge station indicates a nearly imperceptible overestimation of the peak flow, while the peak flow for the Pădurea Neagră gauge station was underestimated by the model with a PEP value of 23\%. According to Moriasi et al. (2007), there is an adequate model performance when the deviation of the evaluated data expressed as a percentage (PBIAS) falls within $\pm 25 \%$. As far as the peak time is concerned, there is a lag of about 14 minutes between the simulated (26,64 m3/s) and observed (26,60 m3/s) peak flows at the Chiribis gauge station and about 51 minutes between the simulated $(10,35 \mathrm{~m} 3 / \mathrm{s})$ and observed $(13,5 \mathrm{~m} 3 / \mathrm{s})$ ones at the Pădurea Neagră gauge station. It is worth mentioning that the validation process was conducted with a high level of confidence since detailed discharge data measured at the gauge stations with a time step of 10 minutes, was available.

\section{CONCLUSIONS}

Even though the model was developed to predict runoff in small watersheds, this study presented a further evaluation and improvement by applying the methodology to the Bistra medium-sized watershed. Unlike the few previous studies focused on the application of the model, this research provided a more powerful validation by using 
measured data at two gauge sites within the watershed. The results reported very high NSE values of 0.84 and 0.73 and adequate PEP values of $0.15 \%$ and $23 \%$ indicating a good level of model performance, when used for larger-sized catchment areas.

On the other hand, the main disadvantage when the model is applied to larger areas is the high quality input data demand. The sensitivity of the hydrologic model outcomes is strongly influenced by the spatial and temporal resolution of the input parameters. A larger-sized basin such as Bistra, usually has a higher heterogeneity of terrain characteristics and receives a more unevenly distributed rainfall, compared to very small one and may require finer resolution data. Better results can be achieved if the user provides detailed information on the spatial distribution of land use, soils and rainfall. Further research is required also on the matter of velocity and travel time computation, taking into consideration the need to account for the spatial distribution of rainfall intensity. Nonetheless, this study revealed that the model does apply well on medium-sized river basins in the absence of high resolution precipitation data.

\section{REFERENCES}

ABAC (Administrația Bazinală de Apă Crișuri), 2009. Planul de management al spatiului hidrografic Crișuri. Administrația Națională Apele Române”, Oradea.

Arseni, M., Roșu, A., Bocăneală, C., Constantin, D.-E. \& Georgescu, L.P., 2017. Flood hazard monitoring using GIS and remote sensing observations. Carpathian Journal of Earth and Environmental Sciences, 12, 2, 329-334.

Barta K., 2004. Modelling Infiltration on Arable Lands. Journal of Hungarian Geomathematics, 2, 16-24.

Centeri, Cs., Barta, K., Jakab, G., Szalai, Z. \& Bíró, Zs., 2009. Comparison of EUROSEM, WEPP, and MEDRUSH model calculations with measured runoff and soil-loss data from rainfall simulations in Hungary. Journal of Plant Nutrition and Soil Science, 172, 6, 789-797.

Corbuș C., 2010. Programul CAVIS pentru determinarea caracteristicilor undelor de viitură singulare. In: Conferinţa Știinţifică Jubiliară a Institutului Naţional de Hidrologie şi Gospodărirea Apelor, "Hidrologia şi gospodărirea apelor - Provocări 2025 pentru dezvoltarea durabilă a resurselor de apă", București, 116-123.

Crăciun, A.I., 2011. Estimarea indirectă, cu ajutorul GIS, a umezelii solului în scopul modelării viiturilor pluviale. Aplicații în Munții Apuseni. Ph.D Thesis, Cluj-Napoca, 278 pp.

Crăciun, A.I., Haidu, I. \& Bilaşco, Şt., 2007. The SCSCN model assisted by G.I.S.- alternative estimation of the hydric runoff in real time. Geographia
Technica, 2, 1, 1-7.

Crăciun, A.I., Haidu, I., Magyari-Sáska, Zs. \& Imbroane, A.I., 2009. Estimation of runoff coefficient according to soil moisture using GIS techniques. Geographia Technica, 4, 2, 1-10.

Domnița M., Crăciun, A.I. \& Haidu I., 2009. GIS in determination of the discharge hydrograph generated by surface runoff for small basins. Geographia Technica, 4, 2, 11-22.

Domnița, M., 2012. Runoff modeling using GIS. Application in torrential basins in the Apuseni Mountains. Ph.D Thesis, Cluj Napoca, 271 pp.

Domniţa, M., Crăciun, A.I., Haidu, I., Magyari-Saska, Zs., 2010a. Geographical Information System module for deriving the flash flood hydrograph in mountainous areas. Proceedings of the 4th European Computing Conference, WSEAS Press, 260-265.

Domniţa, M., Crăciun, A.I., Haidu, I. \& MagyariSaska, Zs., 2010b. GIS used for determination of the maximum discharge in very small basins (under $2 \mathrm{~km} 2$ ). WSEAS Transactions on Environment and Development, 6, 468-477.

Doocy, S., Daniels, A., Murray, S. \& Kirsch, T.D., 2013. The human impact of floods: A historical review of events 1980-2009 and systematic literature review. PLOS Currents Disasters, 5, 1-27.

Dysarz, T., Wicher-Dysarz, J. \& Sojka, M., 2015. Assessment of the Impact of New Investments on Flood Hazard-Study Case: The Bridge on the Warta River near Wronki. Water, 7, 10, 5752-5767.

Gyori, M.M., 2013. Predicția viiturilor rapide în condiții de date limitate. Aplicație la râurile mici din munții Zărandului și Săvârșinului. Ph.D Thesis, ClujNapoca.

Gyori, M.M., Haidu, I. \& Humbert, J. , 2016. Deriving the floodplain in rural areas for high exceedance Probability Having Limited Data Source. Environmental Engineering and Management Journal, 15, 8, 1879-1887.

Haidu I., Crăciun A.I. \& Marian R.A., 2019. Risk scenarios for flash-floods in the rural area generated by combined hazard, technologic and natural, Carpathian Journal of Earth and Environmental Sciences, 14, 1, 181 - 190.

Haidu, I., Batelaan, O., Crăciun, A.I., \& Domnița, M., 2017. GIS module for the estimation of the hillslope torrential peak flow. Environmental Engineering and Management Journal, 16, 5, 1137-1144.

Khaleghi, S. \& Mahmoodi, M., 2017. Assessment of flood hazard zonation in a mountainous area based on GIS and analytical hierarchy process. Carpathian Journal of Earth and Environmental Sciences, 12, 1, 311-322.

Liptay, Z.A., Czigany, S., Pirkhoffer, E. \& Klug, H., 2018. Hydrological modeling of small alpine watersheds with the NAM model. Carpathian Journal of Earth and Environmental Sciences, 13, 1, 235-248.

Liu, J. \& Wang, S.-Y., 2013. Analysis of human 
vulnerability to the extreme rainfall event on 21-22 July 2012 in Beijing, China. Natural Hazards and Earth System Sciences, 13, 11, 2911-2926.

Maidment, D.R., Olivera F., Calver A., Eatherall A., \& Fraczek W., 1996. Unit hydrograph derived from a spatially distributed velocity field. Hydrological Processes, 10, 6, 831-844.

Melesse, A.,M., Graham, W.,D. \& Jordan, J.,D., 2003. Spatially distributed watershed mapping and modeling: GIS-based storm runoff response and hydrograph analysis. Part 2, Journal of Spatial Hydrology, 3,2 1-28.

Melesse, A.M. \& Graham, W.D., 2004. Storm Runoff Prediction Based on a Spatially Distributed Travel Time Method Utilizing Remote Sensing and GIS. Journal of the American Water Resources Association, 40,4, 863-879.

Moriasi, D.N., Arnold J.G., Van Liew, M.W., Bingner, R.L., Harmel, R.D. \& Veith, T.L., 2007. Model evaluation guidelines for systematic quantification of accuracy in watershed simulations. Transactions of the of the American Society of Agricultural and Biological Engineers, 50, 3, 885-900.

Musy, A. \& Higy C., 1998. Hydrologie appliquée, Edition HGA, Bucharest, 368 pp.

Olaya, V., 2004. A gentle introduction to SAGA GIS. Edition 1.1 The SAGA User Group, Göettingen University, Germany, 216 pp. URL: https://sourceforge.net/projects/sagagis/files/SAGA\%20-

\%20Documentation/SAGA\%20Documents/
Satheeshkumar S., Venkateswaran S. \& Kannan R., 2017. Rainfall-runoff estimation using SCS-CN and GIS approach in the Pappiredipatti watershed of the Vaniyar sub basin, South India. Modeling Earth Systems and Environment, 3:24.

Strapazan, C. \& Petrut, M., 2017. Application of Arc Hydro and HEC-HMS model techniques for runoff simulation in the headwater areas of Covasna Watershed (Romania). Geographia Technica, 12, 1, 95-107.

Szilassi, P., Jordan, G., Van Rompaey, A. \& Csillag, G., 2006. Impacts of historical land use changes on erosion and agricultural soil properties in the Kali Basin at Lake Balaton, Hungary. Catena, 68, 2-3, 96-108.

Şarpe, C.A., \& Haidu, I., 2017. Temporal sampling conditions in numerical integration of hydrological systems time series. Geographia Technica, 12, 1, 82- 94.

USACE (US Army Corps of Engineers-Institute For Water Resources), 2000. Hydrologic Modeling System HEC-HMS. Technical Reference Manual. Hydrologic Engineering Center, Davis, CA U.S.A, 149 pp.

Vieux, B.E., 2004. Distributed Hydrologic Modeling Using GIS. 2nd edn.. Kluwer Academic Publishers, Dordrecht, Netherlands, 289 pp.

Voda, A.I., Şarpe, C.A. \& Voda, M., 2018. Methods of maximum discharge computation in ungauged river basins. Review of procedures in Romania. Geographia Technica, 13, 1, 130-137. 